\title{
Removing arsenic from water with an original and modified natural manganese oxide ore: batch kinetic and equilibrium adsorption studies
}

\author{
Thi Thuc Quyen Nguyen ${ }^{1} \cdot$ Paripurnanda Loganathan ${ }^{1} \cdot$ Tien Vinh Nguyen ${ }^{1}$ (D) $\cdot$ Saravanamuthu Vigneswaran ${ }^{1}$
}

Received: 2 September 2019 / Accepted: 3 December 2019

(C) Springer-Verlag GmbH Germany, part of Springer Nature 2019

\begin{abstract}
Arsenic contamination of drinking water is a serious water quality problem in many parts of the world. In this study, a low-cost manganese oxide ore from Vietnam (Vietnamese manganese oxide (VMO)) was firstly evaluated for its performance in arsenate $(\mathrm{As}(\mathrm{V}))$ removal from water. This material contains both $\mathrm{Mn}(25.6 \%)$ and $\mathrm{Fe}(16.1 \%)$ mainly in the form of cryptomelane and goethite minerals. At the initial $\mathrm{As}(\mathrm{V})$ concentration of $0.5 \mathrm{mg} / \mathrm{L}$, the adsorption capacity of original $\mathrm{VMO}$ determined using the Langmuir model was $0.11 \mathrm{mg} / \mathrm{g}$. The modified VMOs produced by coating VMO with iron oxide $\left(\mathrm{Fe}^{\mathrm{a}}-\mathrm{VMO}\right)$ and zirconium oxide $\left(\mathrm{Zr}^{\mathrm{a}}-\mathrm{VMO}\right)$ at $110^{\circ} \mathrm{C}$ and $550^{\circ} \mathrm{C}$ achieved the highest $\mathrm{As}(\mathrm{V})$ adsorption capacity when compared to three other methods of VMO modifications. Langmuir maximum adsorption capacities of $\mathrm{Fe}^{\mathrm{a}}-\mathrm{VMO}$ and $\mathrm{Zr}^{\mathrm{a}}-\mathrm{VMO}$ at $\mathrm{pH} 7.0$ were $2.19 \mathrm{mg} / \mathrm{g}$ and $1.94 \mathrm{mg} / \mathrm{g}$, respectively, nearly twenty times higher than that of the original VMO. Batch equilibrium adsorption data fitted well to the Langmuir, Freundlich, and Temkin models and batch kinetics adsorption data to pseudo-first order, pseudo-second order, and Elovich models. The increase of $\mathrm{pH}$ progressively from 3 to 10 reduced $\mathrm{As}(\mathrm{V})$ adsorption with a maximum reduction of 50$60 \%$ at $\mathrm{pH} 10$ for both original and modified VMOs. The co-existing oxyanions considerably weakened the $\mathrm{As}(\mathrm{V})$ removal efficiency because they competed with $\mathrm{As}(\mathrm{V})$ anions. The competition order was $\mathrm{PO}_{4}{ }^{3-}>\mathrm{SiO}_{3}{ }^{2-}>\mathrm{CO}_{3}{ }^{2-}>\mathrm{SO}_{4}{ }^{2-}$. The characteristics of the original and modified VMOs evaluated using SEM, FTIR, XRD, XRF, surface area, and zeta potential explained the $\mathrm{As}(\mathrm{V})$ adsorption behaviour.
\end{abstract}

Keywords Arsenic $\cdot$ Manganese oxide ore $\cdot$ Iron oxide and zirconium oxide modification · Adsorption $\cdot$ Water treatment

\section{Introduction}

Inorganic arsenic (As) is one of the most serious and challenging pollutants that must be removed from water sources because it is highly toxic in drinking water (Sogaard 2014). Arsenic contamination of water is prevalent in several countries because of natural geological processes and human activities such as mining, chemical industries, and groundwater exploitation (Järup 2003). The range of As concentration in water varies widely from below 0.001 up to $1.0 \mathrm{mg} / \mathrm{L}$; in some places, it can even reach $3.0 \mathrm{mg} / \mathrm{L}$ or higher (Amini et al. 2008; Berg

Responsible Editor: Tito Roberto Cadaval Jr

Tien Vinh Nguyen

Tien.Nguyen@uts.edu.au

1 Faculty of Engineering and IT, University of Technology Sydney (UTS), Sydney, Australia et al. 2001). These concentrations are much higher than the WHO recommended As concentration in drinking water of $0.01 \mathrm{mg} / \mathrm{L}$. In some well-known contaminated regions in Asia, such as Bangladesh, India, Nepal, and Vietnam, the common As concentration in the affected areas is $0.2-0.5 \mathrm{mg} / \mathrm{L}$ (Berg et al. 2007; Berg et al. 2001; Buschmann et al. 2007; Chakraborti et al. 2002; Polya et al. 2005; Smedley and Kinniburgh 2002). The most common As species in groundwater are arsenate $\mathrm{As}(\mathrm{V})$ and arsenite $\mathrm{As}(\mathrm{III})$.

Several studies have demonstrated that various techniques can remove As, for example coagulation, adsorption, ion exchange, and membrane separation (Maiti et al. 2010). Choosing the best appropriate As removal technology is based on many factors: water characteristics, treatment cost, treatment target, treatment efficiency, application conditions, etc. Removing As through adsorption technology has many advantages such as low-cost, simple implementation, high efficiency at a wide range of concentrations, and minimum waste production. It is also suitable for application in decentralized 
systems in affected areas, especially in developing countries where the As problem mostly occurs.

A wide range of materials, both natural and synthetic media, have been used as adsorbents for As removal. Some commercial and synthetic media such as activated carbon, activated alumina, and $\mathrm{Zr}$ resin have produced a very high As removal capacity, i.e. over $10 \mathrm{mg} / \mathrm{g}$ (Mohan and Pittman Jr 2007). Several natural materials or waste industrial/agricultural products (including sand, natural clay, kaolinite clay, bentonite, laterites, manganese ore, iron ore, dry plants, red mud, and fly ash) have emerged as low-cost As removal options (Ahmed 2001; Chakravarty et al. 2002; Chiban et al. 2012). Unlike commercial products, some natural materials cannot reach As adsorption capacity higher than $1 \mathrm{mg} / \mathrm{g}$. For example, the capacity of red mud is $0.514 \mathrm{mg} / \mathrm{g}$, and kaolinite clay is below $0.23 \mathrm{mg} / \mathrm{g}$ (Altundoğan et al. 2002; Mohan and Pittman Jr 2007). In some cases, they could not even meet the As permissible limit for practical application (Kabir and Chowdhury 2017). However, when compared to the most popular and efficient As adsorbent, such as activated carbon which has a high price and regeneration cost, the natural materials' advantages are cost-effectiveness, mechanical stability, and local availability in many Asaffected areas (Chiban et al. 2012). This has encouraged researchers to promote the use of low-cost locally available natural adsorbing materials.

Natural manganese oxide ore is a popular low-cost material that has been used to remove both $\mathrm{As}(\mathrm{III})$ and $\mathrm{As}(\mathrm{V})$ (Ahmed 2001; Chakravarty et al. 2002). However, the adsorption capacity of this ore is generally low (Chakravarty et al. 2002), and for this reason, it is difficult to use it widely and compete with other adsorbents having higher adsorption capacity. Chemical modifications can significantly improve the adsorption capacity of adsorbent media (Asere et al. (2019). For example, modification of clinoptilolite-Ca zeolite using manganese dioxide doubled the adsorption capacity of the unmodified zeolite (Camacho et al. 2011). The modification of biochar using magnetic gelatin also increased As adsorption capacity by about three times (Zhou et al. 2017). Pokhrel and Viraraghavan (2008) reported that iron oxide-coated biomass (IOCB) improved the efficiency significantly in removing As compared to uncoated materials.

Among the many chemicals used as modified agents, water-insoluble metal oxides are the best choice (Khan et al. 2013). Coating low-cost materials with iron (Fe) oxide and zirconium $(\mathrm{Zr})$ oxide is considered an efficient method because of the high affinity of $\mathrm{Fe}$ and $\mathrm{Zr}$ towards As adsorption (Khan et al. 2013; Mohan and Pittman Jr 2007; Pokhrel and Viraraghavan 2008).

In this study, a low-cost manganese oxide ore from Vietnam (Vietnamese manganese oxide (VMO)) with and without modification was tested as an adsorbent for $\mathrm{As}(\mathrm{V})$ removal from aqueous solution in batch kinetics and equilibrium adsorption studies. The modification was carried out by coating $\mathrm{VMO}$ with $\mathrm{Fe}$ oxide and $\mathrm{Zr}$ oxide under four different coating conditions and the modification that produced the highest adsorption capacity was chosen for detailed studies. These included testing the effects of $\mathrm{pH}$ and coexisting anions $\left(\mathrm{PO}_{4}^{3-}, \mathrm{SiO}_{3}^{2-}, \mathrm{SO}_{4}^{2-}, \mathrm{CO}_{3}^{2-}\right)$ on adsorption as well as determining the mechanism of adsorption.

\section{Material and methods}

\section{Feed solution}

In this study, $1 \mathrm{~L}$ synthetic stock solution was prepared by dissolving sodium arsenate $\left(\mathrm{Na}_{2} \mathrm{HAsO}_{4} \cdot 7 \mathrm{H}_{2} \mathrm{O}\right)$ in Milli-Q water to obtain a concentration of $10 \mathrm{mg} \mathrm{As}(\mathrm{V}) / \mathrm{L}$. This stock solution was then diluted to desired concentrations for use in the experiments. The solution's ionic strength was maintained at $1 \times 10^{-3} \mathrm{M} \mathrm{NaNO}_{3}$ and the solution $\mathrm{pH}$ was adjusted to 7.0 \pm 0.2 by adding diluted nitric acid $\left(0.1 \mathrm{M} \mathrm{HNO}_{3}\right)$ and sodium hydroxide $(0.1 \mathrm{M} \mathrm{NaOH})$.

\section{Original adsorbent}

A commercial VMO (particle size $0.1-3.0 \mathrm{~mm}$ ), which is a mineral waste originating from the Tuyen Quang mine, and supplied by Phuong Nam Import-Export Trading and Service Joint Stock Company, Hanoi, Vietnam, was used as an adsorbent for As. It is a low-cost material and employed locally as an adsorbent in water treatment systems. The VMO was ground and sieved into three different sizes $-0.3-0.6 \mathrm{~mm}$, 0.6-1.0 mm, and 1.0-2.0 mm - to study the effect of particle size on the VMO adsorption performance towards As. The sieved materials were washed by deionized distilled water and diluted nitric acid $\left(0.1 \mathrm{M} \mathrm{HNO}_{3}\right)$ to remove any dirt and soluble compounds adhering to its surface. Then it was dried at $100{ }^{\circ} \mathrm{C}$ for $24 \mathrm{~h}$ to remove excess water and moisture before being stored in tightly closed plastic bags.

\section{Modified adsorbents}

Modified VMOs were produced from VMO with a particle size of $0.3-0.6 \mathrm{~mm}$ using four coating methods. Both $\mathrm{Fe}$ and $\mathrm{Zr}$ were used as coating agents. Below are the details of the modification processes:

- $F e^{a}-V M O: 200 \mathrm{~g}$ of VMO was poured into a mixture of $80 \mathrm{~mL} 2 \mathrm{M}$ ferric nitrate nonahydrate $\left(\mathrm{Fe}\left(\mathrm{NO}_{3}\right)_{3} \cdot 9 \mathrm{H}_{2} \mathrm{O}\right)$ and $1 \mathrm{~mL} 10 \mathrm{M} \mathrm{NaOH}$ and shaken manually for $5 \mathrm{~min}$. The mixture was heated at $110{ }^{\circ} \mathrm{C}$ for $4 \mathrm{~h}$ and then at $550{ }^{\circ} \mathrm{C}$ for $3 \mathrm{~h}$ for the first time. After cooling and washing 
Table 1 The equilibrium (Dada et al. 2012) and kinetic (Qiu et al. 2009; Wu et al. 2009) adsorption models

\begin{tabular}{|c|c|c|c|}
\hline Experiment & Model & Equation* & Parameter \\
\hline \multirow[t]{5}{*}{ Equilibrium } & Langmuir & $q_{e}=\frac{q_{m} \cdot k_{L} \cdot C_{e}}{\left(1+k_{L} \cdot C_{e}\right)}$ & $q_{m}, k_{L}, R_{L}$ \\
\hline & & $R_{L}=\frac{1}{1+\left(1+k_{L} \cdot C_{0}\right)}$ & \\
\hline & Freundlich & $q_{e}=k_{f} \cdot C_{e}^{1 / n}$ & $k_{f}, n$ \\
\hline & Temkin & $q_{e}=\frac{R T}{b_{T}} \cdot \ln \left(A_{T} \cdot C_{e}\right)$ & $A_{T}, B, b_{T}$ \\
\hline & & $B=\frac{R T}{b_{T}}$ & \\
\hline \multirow[t]{3}{*}{ Kinetics } & Pseudo-first order & $\frac{d q_{t}}{d t}=k_{1}\left(q_{e}-q_{t}\right)$ & $k_{1}, q_{e}$ \\
\hline & $\begin{array}{l}\text { Pseudo-second } \\
\text { order }\end{array}$ & $\frac{d q_{t}}{d t}=k_{2}\left(q_{e}-q_{t}\right)^{2}$ & $k_{2}, q_{e}$ \\
\hline & Elovich & $\frac{d q_{t}}{d t}=\alpha e^{-\beta q_{t}}$ & $\alpha, \beta$ \\
\hline
\end{tabular}

$* q_{e}$ is the amount of As adsorbed per unit mass of adsorbent $(\mathrm{mg} / \mathrm{g}), q_{m}$ is the maximum amount of the As adsorbed per unit mass of the adsorbent (mg/g), $k_{L}$ is Langmuir isotherm constant (L/mg), $C_{e}$ is the As concentration in solution at equilibrium $(\mathrm{mg} / \mathrm{L}), C_{0}$ is the initial As concentration (mg/L), $R_{L}$ is equilibrium parameter, $k_{f}$ and $n$ are the Freundlich constants, $A_{T}$ is Temkin isotherm equilibrium binding constant $(\mathrm{L} / \mathrm{g}), b_{T}$ is Temkin isotherm constant $(\mathrm{kJ} / \mathrm{mol}), R$ is universal gas constant $(8.314 \mathrm{~J} / \mathrm{mol} / \mathrm{K}), T$ is room temperature at $298 \mathrm{~K}$, and $B$ is constant related to heat of sorption $(\mathrm{J} / \mathrm{mol}) . q_{e}$ is the amount of As adsorbed at equilibrium (mg/g), $q_{t}$ is the amount of As adsorbed at time $t(\mathrm{mg} / \mathrm{g}), k_{1}$ is the rate constant of pseudo-first order adsorption $(\mathrm{L} / \mathrm{h}), k_{2}$ is the rate constant of pseudo-second order $(\mathrm{g} / \mathrm{mg} \mathrm{h}), \alpha$ is the initial adsorption rate $(\mathrm{mg} / \mathrm{g} \mathrm{min})$, and $\beta$ is related to the extent of surface coverage and activation energy for chemisorption $(\mathrm{g} / \mathrm{mg})$

the mixture, $100 \mathrm{~g}$ of this material was poured into a similar mixture as before and heated again at $110^{\circ} \mathrm{C}$ for $20 \mathrm{~h}$. This modification procedure is an adaptation of the method used by Thirunavukkarasu et al. (2003) for preparing iron oxide-coated sand (IOCS-2).

- $F e^{b}-V M O$ : VMO was modified again by impregnation of iron. Ten grams od VMO was mixed with $1 \mathrm{~L}$ ferric chloride hexahydrate $\mathrm{FeCl}_{3} \cdot 6 \mathrm{H}_{2} \mathrm{O}\left(2.0 \mathrm{~g} \mathrm{Fe}^{3+} / \mathrm{L}\right)$ and the mixture was shaken for $1 \mathrm{~h}$ at $120 \mathrm{rpm}$. Then, the $\mathrm{pH}$ of the mixed solution was adjusted to 8.0 by adding $1 \mathrm{M} \mathrm{NaOH}$. After $3 \mathrm{~h}$ of continuous shaking, the shaking speed was reduced to $30 \mathrm{rpm}$ and the suspension was intermittently mixed for $24 \mathrm{~h}$. The material was then rinsed by Milli-Q water to remove unreacted $\mathrm{Fe}$ and dried at $45^{\circ} \mathrm{C}$ for $24 \mathrm{~h}$ (Kalaruban et al. 2016).

- $F e^{c}-V M O$ : This material was prepared by adding $10 \mathrm{~g}$ VMO to $150 \mathrm{~mL}$ solution of $0.1 \mathrm{M}$ ferrous chloride tetrahydrate $\left(\mathrm{FeCl}_{2} \cdot 4 \mathrm{H}_{2} \mathrm{O}\right)$ at $\mathrm{pH} 4.2-4.5$ and agitated at $120 \mathrm{rpm}$ for $24 \mathrm{~h}$ at room temperature $\left(25 \pm 1^{\circ} \mathrm{C}\right)$. This was followed by washing it with $200 \mathrm{~mL}$ Milli-Q water three times and drying at $80{ }^{\circ} \mathrm{C}$ for $4 \mathrm{~h}$ (Gu et al. 2005).

- $F e^{d}-V M O$ : The preparation procedure was similar to that of $\mathrm{Fe}^{\mathrm{c}}$-VMO. However, $20 \mathrm{~mL}$ sodium hypochlorite (13\% $\mathrm{NaClO}$ ) was added four times to the $150 \mathrm{~mL}$ solution during the shaking phase, each at intervals of $6 \mathrm{~h}$. In this process, $\mathrm{pH}$ was maintained at 4.5-5.0 (Gu et al. 2005).

Similarly, $\mathrm{Zr}^{\mathrm{a}}, \mathrm{Zr}^{\mathrm{b}}, \mathrm{Zr}^{\mathrm{c}}$, and $\mathrm{Zr}^{\mathrm{d}}$ were produced by mixing zirconyl chloride octahydrate $\left(\mathrm{ZrOCl}_{2} .8 \mathrm{H}_{2} \mathrm{O}\right)$ instead of the iron salts with VMO according to the above methods.

\section{As(V) adsorption capacity of modified and unmodified VMOs with different particle sizes}

Unmodified VMOs of doses $1-5 \mathrm{~g} / \mathrm{L}$ with particle sizes of $0.3-0.6 \mathrm{~mm}, 0.6-1.0 \mathrm{~mm}$, and $1.0-2.0 \mathrm{~mm}$ were added into $250-\mathrm{mL}$ flasks containing $100 \mathrm{~mL} \mathrm{As}(\mathrm{V})$ solution of $0.1 \mathrm{mg} / \mathrm{L}$ concentration. These flasks were shaken at $120 \mathrm{rpm}$ for $24 \mathrm{~h}$. The supernatant solution was filtered using $0.45 \mu \mathrm{m}$ filters and filtered samples were analysed for As using an ICP-MS instrument (Agilent Technologies 7900 ICP-MS). Similar

Table 2 Metal composition of original and modified VMO determined by XRF

\begin{tabular}{lcclll}
\hline Adsorbent & $\mathrm{Si}(\mathrm{wt} \%)$ & $\mathrm{Mn}(\mathrm{wt} \%)$ & $\mathrm{Fe}(\mathrm{wt} \%)$ & $\mathrm{Zr}(\mathrm{wt} \%)$ & $\mathrm{Al}(\mathrm{wt} \%)$ \\
\hline Before As adsorption & & & & \\
$\mathrm{VMO}$ & $13.0 \pm 0.1$ & $25.6 \pm 0.2$ & $16.1 \pm 0.0$ & 0 & $2.5 \pm 0.1$ \\
$\mathrm{Fe}^{\mathrm{a}}-\mathrm{VMO}$ & $8.7 \pm 0.1$ & $20.9 \pm 0.2$ & $21.9 \pm 0.2$ & 0 & $2.0 \pm 0.1$ \\
$\mathrm{Fe}^{\mathrm{b}}-\mathrm{VMO}$ & $15.2 \pm 0.1$ & $16.7 \pm 0.1$ & $20.0 \pm 0.1$ & 0 & $3.1 \pm 0.1$ \\
$\mathrm{Fe}^{\mathrm{c}}-\mathrm{VMO}$ & $14.4 \pm 0.1$ & $19.9 \pm 0.1$ & $19.0 \pm 0.1$ & 0 & $2.9 \pm 0.1$ \\
$\mathrm{Fe}^{\mathrm{d}}-\mathrm{VMO}$ & $14.3 \pm 0.1$ & $19.7 \pm 0.1$ & $19.1 \pm 0.1$ & 0 & $3.0 \pm 0.1$ \\
$\mathrm{Zr}$-VMO & $7.4 \pm 0.1$ & $22.5 \pm 0.3$ & $12.2 \pm 0.2$ & $9.8 \pm 0.1$ & $1.4 \pm 0.1$ \\
$\mathrm{Zr}$-VMO & $13.0 \pm 0.1$ & $21.6 \pm 0.1$ & $19.0 \pm 0.1$ & $0.1 \pm 0.1$ & $2.9 \pm 0.1$ \\
$\mathrm{Zr}^{\mathrm{c}}-\mathrm{VMO}$ & $13.6 \pm 0.1$ & $23.4 \pm 0.1$ & $18.5 \pm 0.1$ & $0.08 \pm 0.1$ & $2.8 \pm 0.1$ \\
$\mathrm{Zr}$-VMO & $13.7 \pm 0.1$ & $19.9 \pm 0.1$ & $18.9 \pm 0.1$ & $0.5 \pm 0.1$ & $2.8 \pm 0.1$ \\
$\mathrm{After}$ As adsorption & & & & \\
$\mathrm{VMO}$ & $13.1 \pm 0.1$ & $26.0 \pm 0.2$ & $16.4 \pm 0.0$ & 0 & $2.4 \pm 0.1$ \\
$\mathrm{Fe}^{\mathrm{a}}-\mathrm{VMO}$ & $9.9 \pm 0.1$ & $25.0 \pm 0.2$ & $23.1 \pm 0.1$ & 0 & $2.2 \pm 0.1$ \\
$\mathrm{Zr}^{\mathrm{a}}-\mathrm{VMO}$ & $7.6 \pm 0.1$ & $24.2 \pm 0.2$ & $13.6 \pm 0.1$ & $10.2 \pm 0.1$ & $1.3 \pm 0.1$ \\
\hline
\end{tabular}


experiments were also conducted with the eight types of modified VMO of the same particle size of $0.3-0.6 \mathrm{~mm}$. In all studies, the initial $\mathrm{pH}$ and ionic strength were $7.0 \pm 0.2$ and $1 \times 10^{-3} \mathrm{M} \mathrm{NaNO}_{3}$, respectively.

The results (presented in more detail in "Characteristics of adsorbents") demonstrated that VMO of particle size 0.3$0.6 \mathrm{~mm}$ and $\mathrm{Fe}^{\mathrm{a}}-\mathrm{VMO}$ and $\mathrm{Zr}^{\mathrm{a}}-\mathrm{VMO}$ had the highest $\mathrm{As}(\mathrm{V})$ adsorption capacity. Consequently, they were chosen for the subsequent studies and characterization.

\section{Equilibrium and kinetic adsorption of As(V) on VMO, $\mathrm{Fe}^{\mathrm{a}}$-VMO, and $\mathrm{Zr}^{\mathrm{a}}-\mathrm{VMO}$}

All batch experiments were conducted on $\mathrm{VMO}, \mathrm{Fe}^{\mathrm{a}}-\mathrm{VMO}$, and $\mathrm{Zr}^{\mathrm{a}}-\mathrm{VMO}$ (particle size $0.3-0.6 \mathrm{~mm}$ ) at room temperature of $25 \pm 1{ }^{\circ} \mathrm{C}$ and natural $\mathrm{pH}$ of $7.0 \pm 0.2$ (excluding experiments on $\mathrm{pH}$ impact). The ionic strength was kept at $1 \times$ $10^{-3} \mathrm{M} \mathrm{NaNO}_{3}$ for all feed solutions.

The equilibrium adsorption experiments were conducted by adding different adsorbent dosages, i.e. $2.0-14 \mathrm{~g} / \mathrm{L}$ of $\mathrm{VMO}$ and $0.1-2.0 \mathrm{~g} / \mathrm{L}$ of modified $\mathrm{VMO}$, into a set of flasks containing $100 \mathrm{~mL} \mathrm{As}(\mathrm{V})$ solution of $0.5 \mathrm{mg} / \mathrm{L}$. The flasks were agitated on a shaker at $120 \mathrm{rpm}$ for $24 \mathrm{~h}$. The supernatant solutions were filtered using $0.45 \mu \mathrm{m}$ filters and As in filtered samples was analysed.

The amount of $\mathrm{As}(\mathrm{V})$ adsorption at equilibrium was calculated using Eq. 1 (Nur et al. 2014):

$q_{e}=\frac{\left(C_{0-} C_{e}\right) \cdot V}{M}(\mathrm{mg} / \mathrm{g})$

where $C_{0}$ is initial concentration of $\mathrm{As}(\mathrm{V})(\mathrm{mg} / \mathrm{L}), C_{e}$ is equilibrium concentration of $\mathrm{As}(\mathrm{V})(\mathrm{mg} / \mathrm{L}), V$ is volume of solution (L), and $M$ is mass of adsorbent (g).

Adsorption efficiency was calculated using Eq. 2 as follows:

$E(\%)=\frac{\left(C_{0-} C_{e}\right)}{C_{0}} \times 100$

The adsorption kinetics experiment was conducted by adding predetermined amounts of VMO $(2 \mathrm{~g} / \mathrm{L})$ and modified VMO $(0.1 \mathrm{mg} / \mathrm{L})$ into a set of flasks containing $100 \mathrm{~mL}$ solution of $0.5 \mathrm{mg} / \mathrm{L} \mathrm{As}(\mathrm{V})$. The flasks were then agitated at $120 \mathrm{rpm}$, and samples were taken at different time intervals, ranging from $5 \mathrm{~min}$ to $24 \mathrm{~h}$.

The adsorption equilibrium and kinetic data was modelled using common adsorption models (Table 1).

\section{pH influence on $\mathbf{A s}(\mathbf{V})$ adsorption}

Experiments on $\mathrm{pH}$ influence on $\mathrm{As}(\mathrm{V})$ adsorption were conducted at a $\mathrm{pH}$ range from 3.0 to 10.0 . Here, $\mathrm{pH}$ of $\mathrm{As}(\mathrm{V})$ solution was adjusted using $0.1 \mathrm{M} \mathrm{HNO}_{3}$ and $0.1 \mathrm{M} \mathrm{NaOH}$ solutions after the required amounts of modified VMO $(0.3 \mathrm{~g} /$
L) and unmodified VMO ( $3 \mathrm{~g} / \mathrm{L})$ were added to a set of glass flasks containing $100 \mathrm{~mL}$ of $0.5 \mathrm{mg} \mathrm{As}(\mathrm{V}) / \mathrm{L}$. The experimental procedure was similar to the previous equilibrium adsorption experiment.

\section{Coexisting anions' influence on $\mathrm{As}(\mathrm{V})$ adsorption}

A study on the influence of coexisting anions on $\mathrm{As}(\mathrm{V})$ adsorption was carried out utilizing four typical anions, i.e. phosphate $\left(\mathrm{PO}_{4}^{3-}\right)$, sulphate $\left(\mathrm{SO}_{4}^{2-}\right)$, silicate $\left(\mathrm{SiO}_{3}^{2-}\right)$, and bicarbonate $\left(\mathrm{CO}_{3}^{2-}\right)$. In this experiment, $\mathrm{Na}^{+}$salts of different anions of concentration from 0.1 to $20 \mathrm{mg} / \mathrm{L}$ were added separately into $100 \mathrm{~mL}$ solutions containing $0.5 \mathrm{mg} \mathrm{As}(\mathrm{V}) / \mathrm{L}$. Predetermined amounts of $0.1 \mathrm{~g}$ modified VMO and $1 \mathrm{~g}$ unmodified VMO were added to the above solutions. The experimental procedure was similar to that of the previous equilibrium adsorption experiments.

\section{Adsorbent characterization}

Characteristics of unmodified and modified VMOs were determined by the following: X-ray diffraction (XRD, Bruker D2 Phaser instrument); scanning electron microscopy (SEM, Quanta-650 instrument); Fourier transform infrared (FTIR, Nicolet iS5 FT-IR Spectrometer); X-ray fluorescence (XRF, Olympus Vanta $\mathrm{M}$ series); and Brunauer-Emmett-Teller (BET) nitrogen adsorption.

Zeta potential measurement was done to determine the surface charge characteristics of materials before and after $\mathrm{As}(\mathrm{V})$ adsorption. Here, the zeta potentials of suspensions prepared by adding $0.1 \mathrm{~g}$ of fine material $(<0.75 \mu \mathrm{m})$ in $100 \mathrm{~mL}$ Milli$\mathrm{Q}$ water at different $\mathrm{pH}$ levels were measured using a Zetasizer nano instrument, Nano ZS Zen 3600.

\section{Results and discussion}

\section{Characteristics of adsorbents}

Elemental compositions of unmodified and modified VMO as determined by XRF are shown in Table 2. The unmodified VMO had high percentages of Mn and Fe and a moderate percentage of $\mathrm{Si}$, but no $\mathrm{Zr}$. The composition was found to be strongly dependent on the coating conditions. The modified materials, $\mathrm{Fe}^{\mathrm{a}}-\mathrm{VMO}$ and $\mathrm{Zr}^{\mathrm{a}}-\mathrm{VMO}$, produced by the first modification process (mixing original $\mathrm{VMO}$ with ferric nitrate and sodium hydroxide and heating at high temperature) had the highest percentage of $\mathrm{Fe}$ and $\mathrm{Zr}$ after modification $(21.9 \%$ and $9.8 \%$, respectively). Coating metals on VMO increased the percentages of these metals in $\mathrm{Fe}^{\mathrm{a}}-\mathrm{VMO}$ and $\mathrm{Zr}^{\mathrm{a}}-\mathrm{VMO}$ by approximately 6 and $10 \%$, respectively. Additionally, after $\mathrm{As}(\mathrm{V})$ adsorption, the percentages of $\mathrm{Fe}$ and $\mathrm{Zr}$ did not 
decrease, indicating a strong coating of these metals. Therefore, there is no risk of heavy metals leaching from the adsorbents and creating secondary pollution in the treated water.

Figure 1a-f shows the surface morphologies of original $\mathrm{VMO}$ and $\mathrm{Fe}^{\mathrm{a}}-\mathrm{VMO}$ and $\mathrm{Zr}^{\mathrm{a}}-\mathrm{VMO}$, before and after $\mathrm{As}$ adsorption determined by SEM at a high magnification of $x$ 3200 , respectively. The relatively irregular and heterogeneous surface morphology of the three materials can be clearly seen in these figures. The images also indicated that both $\mathrm{Fe}^{\mathrm{a}}-\mathrm{VMO}$ and $\mathrm{Zr}^{\mathrm{a}}$-VMO possessed more porous layers/channels than the original VMO. No visible changes in the surface morphologies of the materials were observed after As adsorption.

A material's adsorption ability strongly depends on its mineral components. According to the XRD diagram (Fig. 2), $\mathrm{VMO}$ consists of four main minerals, namely quartz, goethite, cryptomelane, and muscovite. Quartz and muscovite contributed to the high content of silicon (13\%) in VMO; goethite to the high content of $\mathrm{Fe}(16.1 \%)$; and cryptomelane to the high content of Mn (25.6\%) (Table 2). Fe modification of VMO slightly changed the XRD pattern. This modification produced new peak characteristics of haematite (an Fe oxide mineral). It also appears that the goethite peaks in the unmodified VMO were reduced in size. This indicates that some of the goethite might have got transformed into haematite at the high temperatures used in the modification procedure and/or the $\mathrm{Fe}$ coatings might have produced the haematite mineral. $\mathrm{Zr}$ coating of VMO also produced new XRD peaks which are characteristics of zirconia minerals such as zirconia/zirconolite. It could also be possible that the $\mathrm{Fe}$ and $\mathrm{Zr}$ added might have formed some amorphous (non-crystalline) compounds which cannot be identified by XRD. As adsorption did not change the XRD pattern probably either because of the small amounts of As concentration compared to other elements in the adsorbents or the As compounds formed were amorphous that cannot be detected by XRD. The haematite produced as a result of $\mathrm{Fe}$ and $\mathrm{Zr}$ coatings at high temperature and reduction in the peak heights of goethite is expected to increase the $\mathrm{As}(\mathrm{V})$ adsorption capacity of VMO. Mamindy-Pajany et al. (2011) reported that $\mathrm{As}(\mathrm{V})$ adsorption capacity of haematite is more than double that of goethite. The zirconia mineral produced by $\mathrm{Zr}$ coating of $\mathrm{VMO}$ is also expected to increase the As(V) adsorption capacity (Hang et al. 2011).

BET surface areas of VMO and its modified forms were 27.1 and $37.1-37.5 \mathrm{~m}^{2} / \mathrm{g}$, respectively (Table 3 ). These values are higher than those of many other natural As adsorbents such as gibbsite, goethite, kaolinite, and iron oxide-coated sand (Mohan and Pittman Jr 2007). However, their BET surface area values are lower than those of the popular commercial adsorbents such as activated carbon and activated alumina (Mohan and Pittman Jr 2007). Table 3 also shows that the surface area of VMO increased significantly after
Fig. 1 SEM images of VMO before, after coating, and adsorption. Before As adsorption: a VMO, b Fe ${ }^{\mathrm{a}}-\mathrm{VMO}$, and $\mathbf{c} \mathrm{Zr}^{\mathrm{a}}-$ VMO. After As adsorption: d $\mathrm{VMO}+\mathrm{As}, \mathbf{e ~} \mathrm{Fe}^{\mathrm{a}}-\mathrm{VMO}+\mathrm{As}$, and $\mathbf{f} \mathrm{Zr}^{\mathrm{a}}-\mathrm{VMO}+\mathrm{As}$

\section{Before As adsorption}

(a) VMO

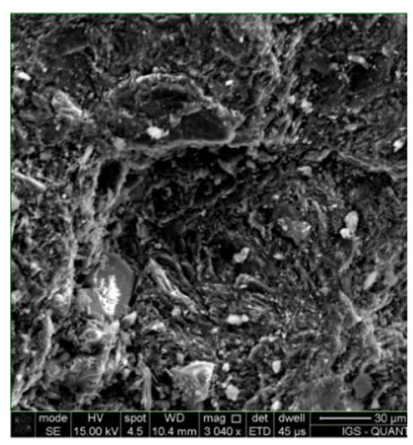

(b) $\mathrm{Fe}^{\mathrm{a}}-\mathrm{VMO}$

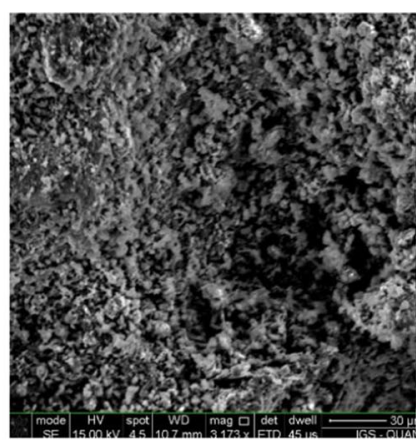

(c) $\mathrm{Zr}^{\mathrm{a}}-\mathrm{VMO}$

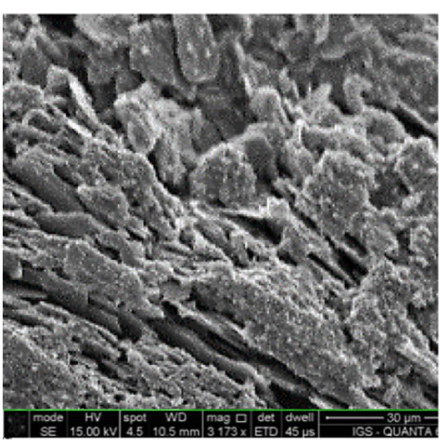

After As adsorption

(d) $\mathrm{VMO}+\mathrm{As}$

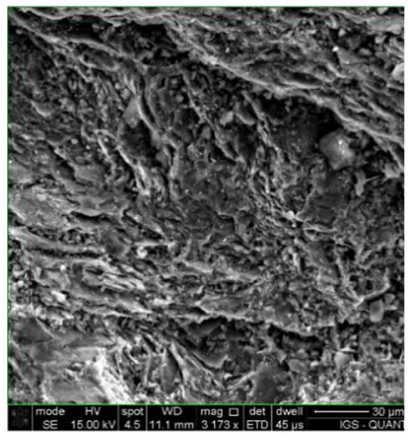

(e) $\mathrm{Fe}^{\mathrm{a}}-\mathrm{VMO}+\mathrm{As}$

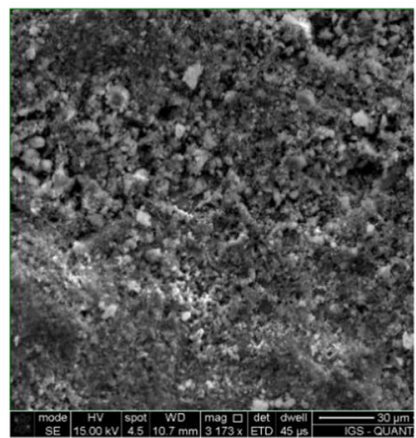

(f) $\mathrm{Zr}^{\mathrm{a}}-\mathrm{VMO}+\mathrm{As}$

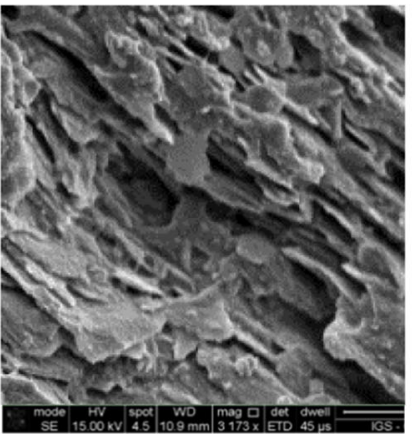


Fig. 2 XRD diagram of VMO and modified VMOs before and after As adsorption
Before As adsorption

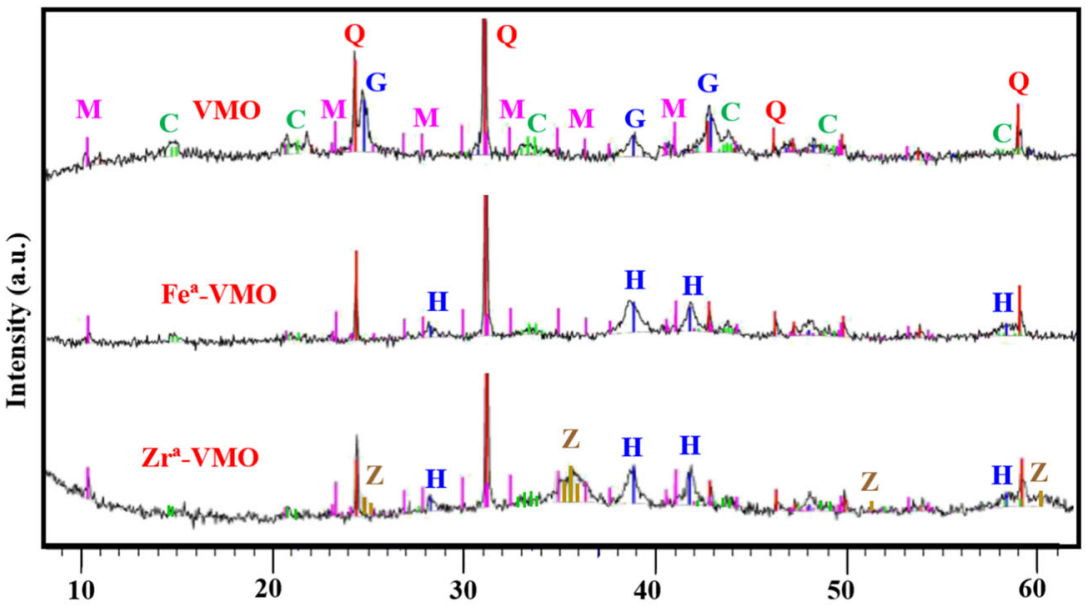

After As adsorption

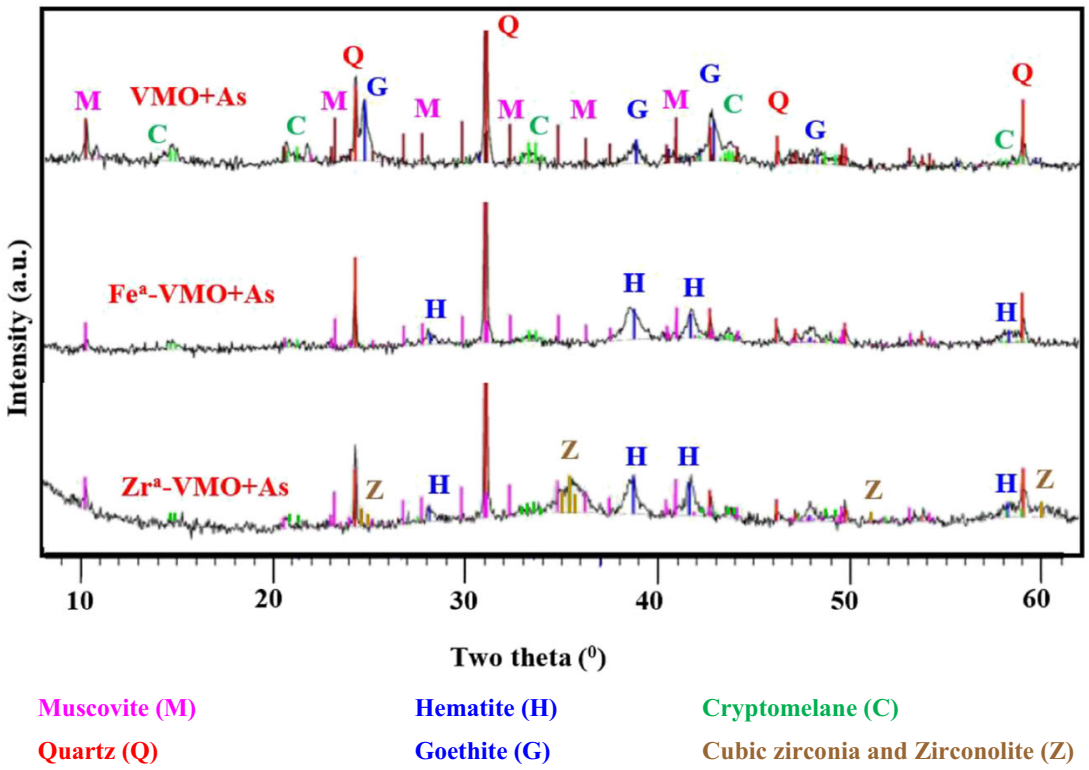

modification. This may have been triggered by the creation of porous forms of $\mathrm{Fe}$ and $\mathrm{Zr}$ precipitated particles. However, the BET surface area and pore volume of both original and modified VMO decreased after adsorption (Table 3). It could be because of the adsorption of $\mathrm{As}(\mathrm{V}) /$ or formation of $\mathrm{As}(\mathrm{V})$ compounds on the surface of the adsorbent and filling-up of some of the pores inside the adsorbent.

FTIR diagrams (Fig. 3) depict the presence of some chemical bonds on the adsorbents before and after $\mathrm{As}(\mathrm{V})$ adsorption process. Evaluation of the differences in the peak intensity,
Table 3 BET surface area and pore volume of adsorbents

\begin{tabular}{llllll}
\hline \multirow{2}{*}{ Adsorbent } & \multicolumn{2}{l}{ Before As(V) adsorption } & & \multicolumn{2}{l}{ After As(V) adsorption } \\
\cline { 2 - 3 } \cline { 5 - 6 } \cline { 5 - 6 } & BET $\left(\mathrm{m}^{2} / \mathrm{g}\right)$ & Pore volume $\left(\mathrm{cm}^{3} / \mathrm{g}\right)$ & & BET $\left(\mathrm{m}^{2} / \mathrm{g}\right)$ & Pore volume $\left(\mathrm{cm}^{3} / \mathrm{g}\right)$ \\
\hline $\mathrm{VMO}$ & 27.1 & 0.0022 & & 17.3 & 0.0012 \\
$\mathrm{Fe}^{\mathrm{a}}-\mathrm{VMO}$ & 37.5 & 0.0017 & 24.4 & 0.0004 \\
$\mathrm{Zr}^{\mathrm{a}}-\mathrm{VMO}$ & 37.1 & 0.0022 & 26.6 & 0.0006 \\
\hline
\end{tabular}


Fig. 3 FTIR diagram of original and modified VMO a before and b after $\mathrm{As}(\mathrm{V})$ adsorption (a) Before adsorption

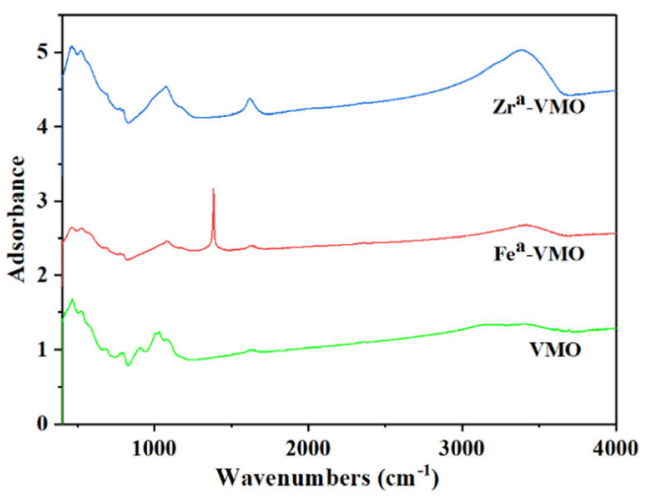

(b) After adsorption

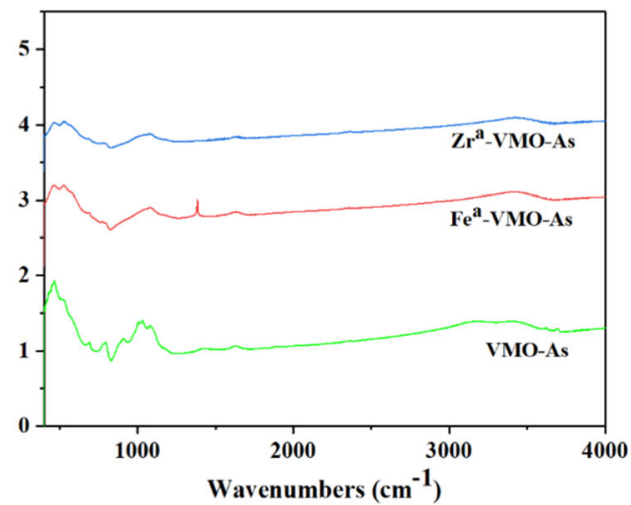

peak shifting, and peak appearance (or disappearance) indicates the types of interaction between surface chemical groups and absorbed As(V).

Generally, the FTIR shapes of the three adsorbents are not too different. After coating, some new peaks appeared that represent new bonds between Fe and $\mathrm{Zr}$ with available functional groups. Figure 3 a shows that a vibrational spectrum exhibited broad $\mathrm{O}-\mathrm{H}$ stretching peaks between 3700 and $3300 \mathrm{~cm}^{-1}$, and $\mathrm{O}-\mathrm{H}$ bending at $1640 \mathrm{~cm}^{-1}$ (Myneni et al. 1998; Petit and Puskar 2018; Tomić et al. 2011). The peak of $1384 \mathrm{~cm}^{-1}$ could be ascribed to the vibration of $\mathrm{C}-\mathrm{H}$ (Delva et al. 2013). The bands between
1100 and $900 \mathrm{~cm}^{-1}$ are normally assigned to $\mathrm{Fe}-\mathrm{OH}$ bending, $\mathrm{Al}-\mathrm{OH}$ bending, and $\mathrm{Si}-\mathrm{O}$ stretching vibration (Tomić et al. 2011; Zhang et al. 2009). The peaks at $794 \mathrm{~cm}^{-1}$ and nearby could be attributed to $\mathrm{Fe}-\mathrm{O}$ (Jia et al. 2007; Tomić et al. 2011). Many peaks were also observed at 525, 524, 523 and 466, 454, $419 \mathrm{~cm}^{-1}$. According to previous reports, these peaks could be assigned to the functional groups of metal such as $\mathrm{Mn}-$ $\mathrm{O}, \mathrm{Mn}-\mathrm{O}-\mathrm{M}, \mathrm{Zr}-\mathrm{O}-\mathrm{Zr}, \mathrm{Si}-\mathrm{O}-\mathrm{Al}$, and $\mathrm{Si}-\mathrm{O}-\mathrm{Si}$ (Markovski et al. 2014; Tomić et al. 2011).

Figure $3 \mathrm{~b}$ illustrates that all peaks of the adsorbents reduced evenly after adsorption. Moreover, it shows that no new group
Fig. 4 Zeta potential of adsorbents $\mathbf{a}$ before and $\mathbf{b}$ after $\mathrm{As}(\mathrm{V})$ adsorption (a)

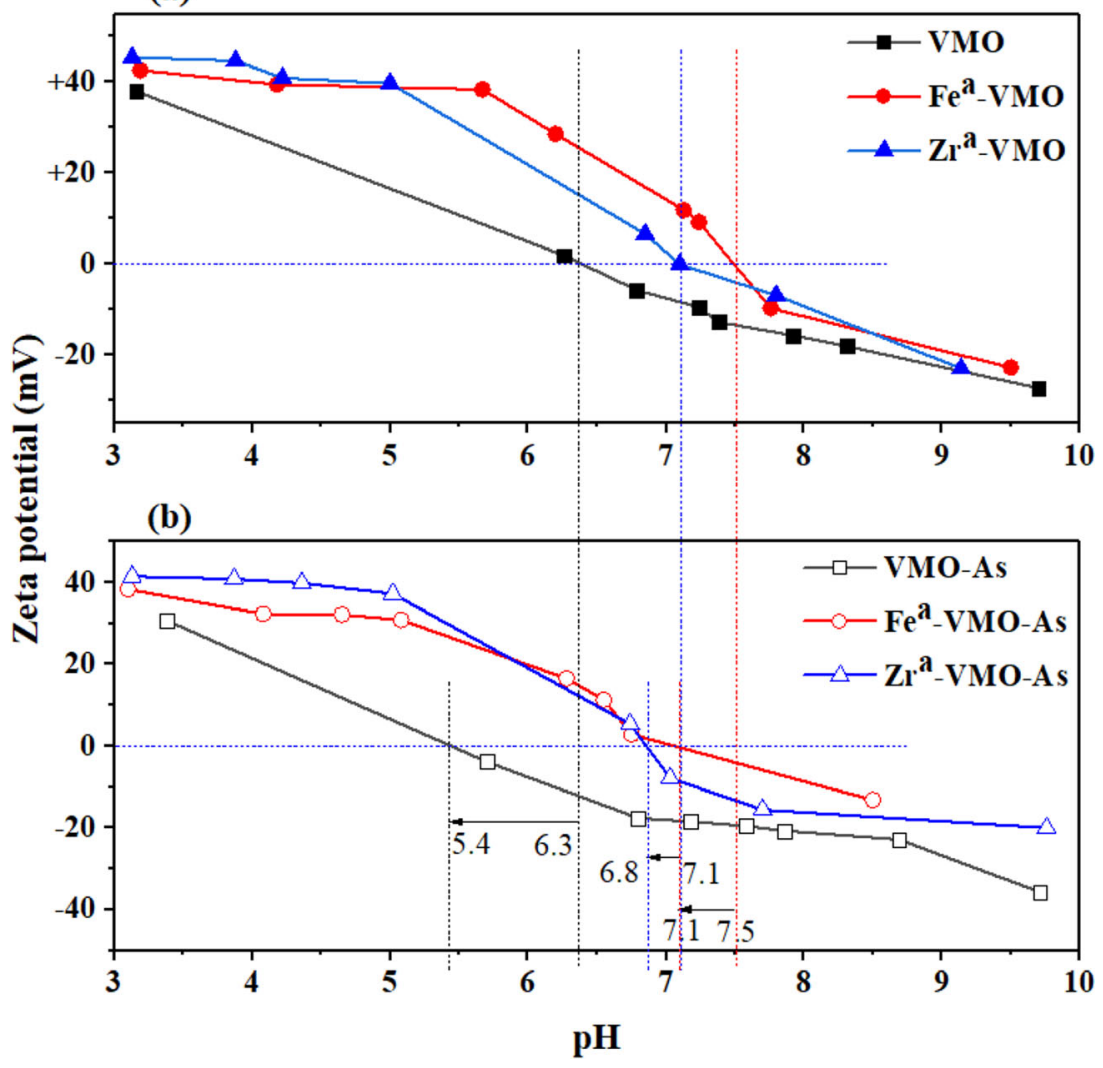


appears in the FTIR diagram. It means that As(V) only reacted with the available functional groups of adsorbents.

Zeta potential of original and modified VMOs at different $\mathrm{pH}$ levels is presented in Fig. 4. The data shows that zeta potentials of $\mathrm{Fe}^{\mathrm{a}}-\mathrm{VMO}$ and $\mathrm{Zr}^{\mathrm{a}}-\mathrm{VMO}$ were more positive than unmodified VMO at all pH levels (Fig. 4a). This means that the impregnation of $\mathrm{Fe}$ and $\mathrm{Zr}$ on $\mathrm{VMO}$ increased the surface positive charge of VMO. As(V) often exists in anionic forms, depending on $\mathrm{pH}$ in water (monovalent $\mathrm{H}_{2} \mathrm{AsO}_{4}{ }^{-}$, divalent $\mathrm{HAsO}_{4}{ }^{2-}$, and trivalent $\mathrm{AsO}_{4}{ }^{3-}$ within the $\mathrm{pH}$ range from approximately 3.0 to $6.0,7.0$ to 11 , and 12 to 14 , respectively) (Mondal et al. 2007). Therefore, the appearance of a more positive charge on modified VMO is favourable for $\mathrm{As}(\mathrm{V})$ removal from water through electrostatic adsorption forces.

The zero point of charges ( $\mathrm{ZPC}, \mathrm{pH}$ at which net surface charge is zero) of VMO, $\mathrm{Fe}^{\mathrm{a}}-\mathrm{VMO}$, and $\mathrm{Zr}^{\mathrm{a}}-\mathrm{VMO}$ were at $\mathrm{pH}$ $6.3,7.1$, and 7.5, respectively. At $\mathrm{pH}$ lower than ZPC, the zeta potentials were more positive and at $\mathrm{pH}$ higher than $\mathrm{ZPC}$, they were more negative (Loganathan et al. 2014; Oladoja and Helmreich 2014). During As(V) adsorption process, because $\mathrm{As}(\mathrm{V})$ exits in negatively charged forms, the original and modified VMO had a better tendency to adsorb As(V) at lower $\mathrm{pH}$ through electrostatic forces. In contrast, at higher $\mathrm{pH}$, especially at basic conditions, the surface charges of original and modified VMO change from positive to negative. This leads to a reduction of $\mathrm{As}(\mathrm{V})$ adsorption capacity of these materials.

Figure $4 \mathrm{~b}$ shows that the negative zeta potentials decreased at all $\mathrm{pH}$ levels and the zero point of charge reduced when the negatively charged As(V) adsorbed on all adsorbents. The decrease of zeta potential indicates that As species were adsorbed on the surface of the adsorbent by inner-sphere complexation as well (ligand exchange) (Kalaruban et al. 2016; Loganathan et al. 2014).

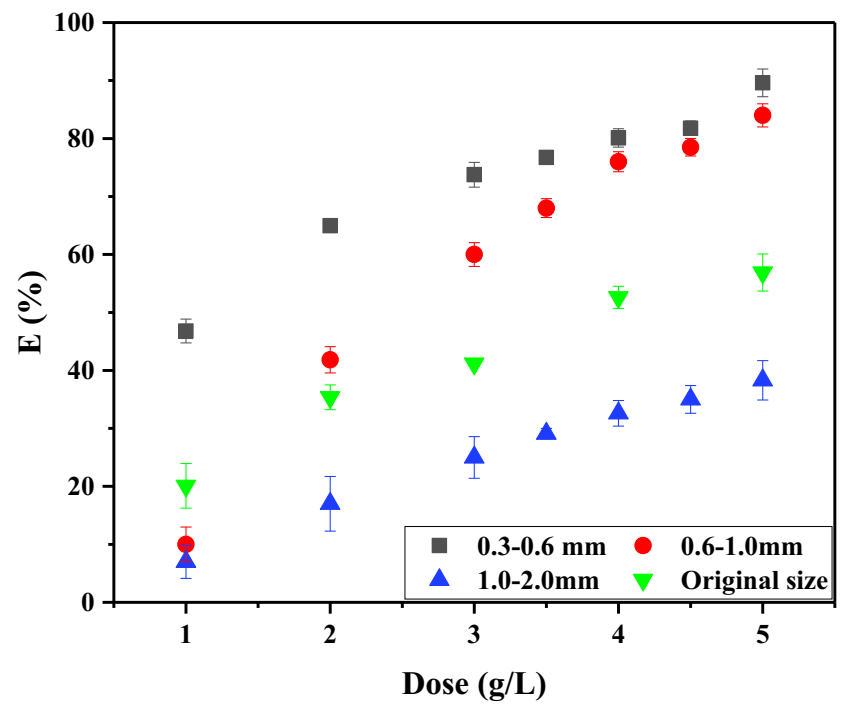

Fig. 5 Effect of particle size on $\mathrm{As}(\mathrm{V})$ removal efficiency
Effect of particle size on $\mathrm{As}(\mathrm{V})$ adsorption

$\mathrm{As}(\mathrm{V})$ adsorption efficiency (E\%) increased with adsorbent doses and reduction in particle size (Fig. 5). At the highest dosage of $5 \mathrm{~g} / \mathrm{L}$, the $\mathrm{E} \%$ of particle size $1.0-2.0 \mathrm{~mm}$ was only $38 \%$ while that of smaller sizes of $0.3-0.6 \mathrm{~mm}$ and $0.6-$ $1.0 \mathrm{~mm}$ reached up to $90 \%$ and $84 \%$, respectively. With the original commercial size, which is a mix of all sizes, E\% was approximately $52 \%$. The particle size of $0.3-0.6 \mathrm{~mm}$ was chosen for experimentation in the subsequent studies because of its highest $\mathrm{E} \%$.

\section{Effect of modification method on $\mathrm{As}(\mathrm{V})$ adsorption}

Figure 6 shows that the coating of Fe and $\mathrm{Zr}$ on $\mathrm{VMO}$ material has improved the material's capacity to remove As $(\mathrm{V})$. However, the level of improvement strongly depended on the modification methods. The $\mathrm{Fe}^{\mathrm{a}}-\mathrm{VMO}$ and $\mathrm{Zr}^{\mathrm{a}}-\mathrm{VMO}$ had the highest improvement. At the dose of $1 \mathrm{~g}$, the $\mathrm{As}(\mathrm{V})$ removal efficiency of modified $\mathrm{Fe}^{\mathrm{a}}-\mathrm{VMO}$ and $\mathrm{Zr}^{\mathrm{a}}-\mathrm{VMO}$ was nearly five times higher than that of the unmodified VMO. The other three modification processes were less effective and only a slight improvement in $\mathrm{As}(\mathrm{V})$ removal was observed.

Temperature played an important role in the effectiveness of the modification processes. The $\mathrm{Fe}^{\mathrm{a}}$ and $\mathrm{Zr}^{\mathrm{a}}$ modification method applied to the production of $\mathrm{Fe}^{\mathrm{a}}-\mathrm{VMO}$ and $\mathrm{Zr}^{\mathrm{a}}-\mathrm{VMO}$ involved a light agitation followed by heating at high temperature of $110^{\circ} \mathrm{C}$ and $550^{\circ} \mathrm{C}$. Here, the modification temperatures were higher than those used in the other three methods (less than $80^{\circ} \mathrm{C}$ ). At extremely high temperature, the coating agents might have adhered strongly to the surface of the VMO. Solutions used to wash $\mathrm{Fe}^{\mathrm{a}}-\mathrm{VMO}$ and $\mathrm{Zr}^{\mathrm{a}}-\mathrm{VMO}$ after their preparation were colourless compared to those in other preparations, suggesting strong coatings at high temperature. The $\mathrm{Fe}$ and $\mathrm{Zr}$ contents of these modifications were also higher than those produced at lower temperatures (Table 2). Moreover, a high temperature would also have raised the surface area of the samples (Thirunavukkarasu et al. 2003). Based on these findings, $\mathrm{Fe}^{\mathrm{a}}-\mathrm{VMO}, \mathrm{Zr}^{\mathrm{a}}-\mathrm{VMO}$, and unmodified $\mathrm{VMO}$ were used in the subsequent studies.

\section{Equilibrium and kinetics adsorption studies}

\section{Equilibrium adsorption isotherms}

The equilibrium adsorption experiments for the three adsorbents were conducted at $\mathrm{pH} 7.0 \pm 0.2$ with different adsorbent dosages. The Langmuir, Freundlich, and Temkin models were employed to describe the data of the adsorption isotherms (Fig. 7). Table 4 shows that the experimental data fitted well to all three isotherm models with the Freundlich model having the best fit $\left(R^{2}=0.90\right.$ $0.97)$, followed by the Langmuir $\left(R^{2}=0.87-0.95\right)$ and 

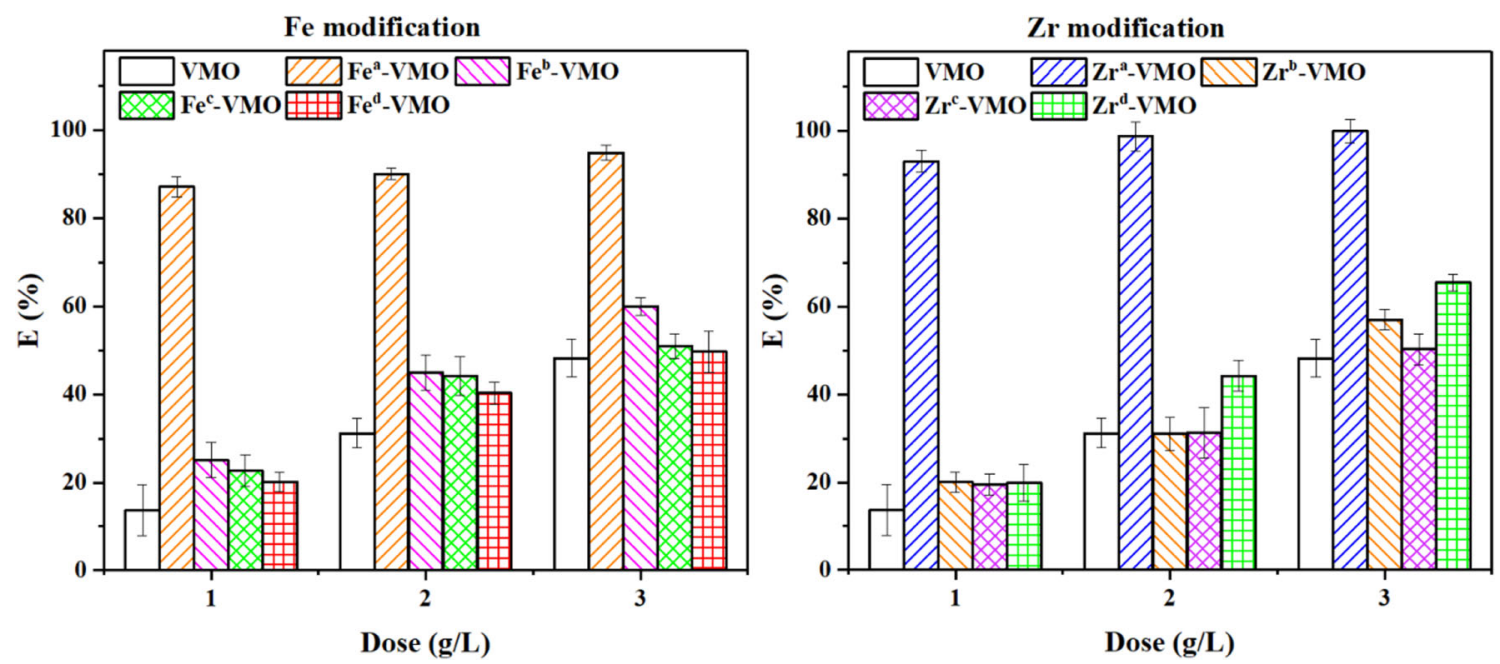

Fig. 6 Effect of different methods of VMO modification on As(V) removal efficiency

Temkin $\left(R^{2}=0.82-0.95\right)$. Better fit to the Freundlich model is probably because of the heterogeneous adsorption sites on VMO and modified VMO such as the different adsorption sites on $\mathrm{Mn}$ and Fe minerals (Fig. 2) and $\mathrm{Zr}$ and Fe coatings. The Langmuir adsorption capacity of VMO increased considerably after modification. Adsorption capacities of $\mathrm{Fe}^{\mathrm{a}}$-VMO and $\mathrm{Zr}^{\mathrm{a}}$-VMO were $2.19 \mathrm{mg} \mathrm{As} / \mathrm{g}$ and $1.94 \mathrm{mg} \mathrm{As} / \mathrm{L}$, respectively. These values are nearly twenty times higher than that of the original VMO $(0.11 \mathrm{mg} \mathrm{As} / \mathrm{g}$ ) (Table 4). It indicates that the presence of $\mathrm{Fe}^{3+}$ and $\mathrm{Zr}^{4+}$ ions on the surface of VMO improved significantly the $\mathrm{As}(\mathrm{V})$ adsorption capacity of VMO. The improvement is due to the strong adsorption of the anionic arsenic species on $\mathrm{Fe}^{3+}$ and $\mathrm{Zr}^{4+}$ hydroxide/ oxides on the surface of VMO (Loganathan et al. 2014; Sogaard 2014). The new minerals (haematite, zirconia/ zirconolite, and amorphous minerals) formed as a result

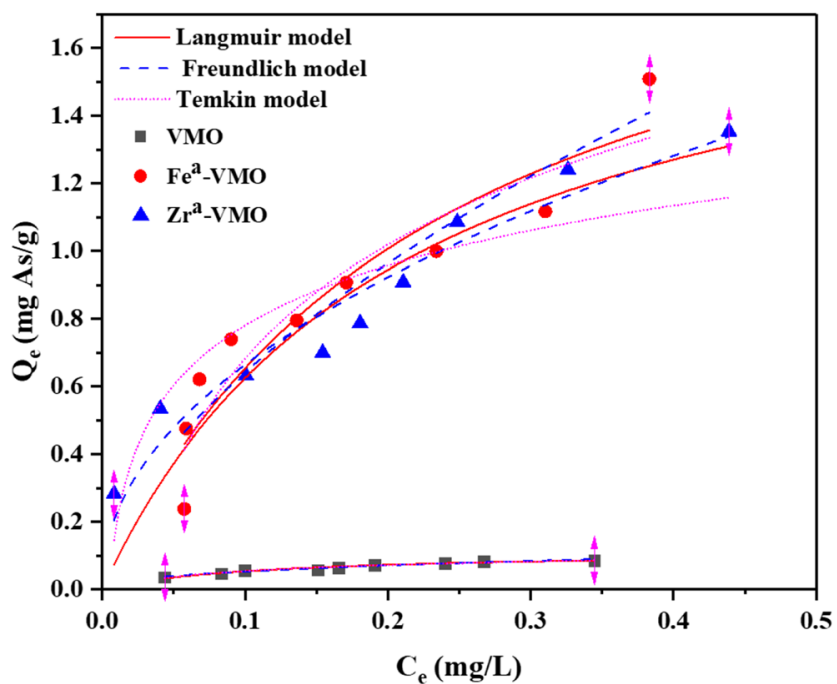

Fig. 7 Batch equilibrium adsorption models fit adsorption data for VMO and modified forms of VMO of Fe and $\mathrm{Zr}$ coatings (Fig. 2) would have enhanced the adsorption capacities as discussed in "Characteristics of adsorbents."

The $R_{L}$ value obtained from the Langmuir model fit indicates the nature of adsorption. Adsorption is considered unfavourable if $R_{L}>1$, linear if $R_{L}=1$, favourable if $0<R_{L}$ $<1$, and irreversible if $R_{L}=0$ (Dada et al. 2012). The calculated $R_{L}$ data of $\mathrm{VMO}, \mathrm{Fe}^{\mathrm{a}}-\mathrm{VMO}$, and $\mathrm{Zr}^{\mathrm{a}}$-VMO were 0.15 , 0.24 , and 0.23 , respectively (Table 4 ). All these values are between 0 and 1 indicating that the adsorption process is favourable for both original and modified VMOs.

In contrast to the Langmuir model, the Freundlich model is used to depict the adsorption characteristics for the heterogeneous surface with multilayer adsorption (Dada et al. 2012). The calculated $k_{f}$ parameter value from the Freundlich model decreased in the following order: $\mathrm{Fe}^{\mathrm{a}}-\mathrm{VMO}(2.48)>\mathrm{Zr}^{\mathrm{a}}$ VMO (1.98) > VMO (0.14). This is in the same order of

Table 4 Parameter values for batch equilibrium adsorption models

\begin{tabular}{llccc}
\hline \multirow{2}{*}{ Model } & Parameter & \multicolumn{3}{l}{ Adsorbent } \\
\cline { 3 - 5 } & & $\mathrm{VMO}$ & $\begin{array}{l}\mathrm{Fe}^{\mathrm{a}}- \\
\mathrm{VMO}\end{array}$ & $\begin{array}{l}\mathrm{Zr}^{\mathrm{a}}- \\
\mathrm{VMO}\end{array}$ \\
\hline \multirow{2}{*}{ Langmuir } & $q_{m}(\mathrm{mg} \mathrm{As} / \mathrm{g})$ & 0.11 & 2.19 & 1.94 \\
& $k_{L}(\mathrm{~L} / \mathrm{mg})$ & 8.93 & 4.24 & 4.75 \\
& $R_{L}$ & 0.15 & 0.24 & 0.23 \\
& $R^{2}$ & 0.95 & 0.89 & 0.87 \\
Freundlich & $k_{f}(\mathrm{mg} / \mathrm{g})(\mathrm{L} / \mathrm{mg})^{1 / n}$ & 0.14 & 2.48 & 1.98 \\
& $N$ & 2.34 & 1.70 & 2.11 \\
& $R^{2}$ & 0.97 & 0.90 & 0.95 \\
& $A_{T}(\mathrm{~L} / \mathrm{g})$ & 84.27 & 40.63 & 211.75 \\
& $B(\mathrm{~J} / \mathrm{mol})$ & 0.025 & 0.49 & 0.26 \\
& $b_{T}(\mathrm{~kJ} / \mathrm{mol})$ & 99.1 & 5.1 & 9.5 \\
& $R^{2}$ & 0.95 & 0.90 & 0.82 \\
\hline
\end{tabular}


As(V) adsorption capacity calculated using the Langmuir model. Additionally, all values of $1 / n$ are below 1 indicating that the adsorption of $\mathrm{As}(\mathrm{V})$ by these adsorbents is favourable confirming the findings from Langmuir $R_{L}$ values.

Unlike the Langmuir and Freundlich models, the Temkin model is usually used for heterogeneous surface energy systems (Erhayem et al. 2015; Shahmohammadi-Kalalagh 2011). It contains a factor that explicitly takes into account the adsorbent-adsorbate interactions (Dada et al. 2012). According to the calculated data in Table 4 , the $B$ values related to heat of sorption are positive indicating that the sorption process is exothermic and the values are higher for modified VMOs (Puttamat and Pavarajarn 2016).

In comparison with adsorbents that have similar iron oxide modification such as IOCS and IOCS-2, the modifications made in $\mathrm{Fe}^{\mathrm{a}}-\mathrm{VMO}$ and $\mathrm{Zr}^{\mathrm{a}}-\mathrm{VMO}$ improved the $\mathrm{As}(\mathrm{V})$ adsorption capacity considerably. For example, IOCS and IOCS-2 had As(V) adsorption capacity of $0.018 \mathrm{mg} / \mathrm{g}$ and $0.008 \mathrm{mg} / \mathrm{g}$ at initial As(V) concentration of $0.325 \mathrm{mg} / \mathrm{L}$ and $0.1 \mathrm{mg} / \mathrm{L}$, respectively (Mohan and Pittman Jr 2007; Thirunavukkarasu et al. 2001). Nevertheless, in comparison with other natural manganese ores, As(V) adsorption capacity of unmodified VMO is lower. For instance, manganese oxide (MO1) from France had a capacity of $0.172 \mathrm{mg} / \mathrm{g}$ at an initial $\mathrm{As}(\mathrm{V})$ concentration $\left(C_{0}\right)<1 \mathrm{mg}$ As $(\mathrm{V}) / \mathrm{L}$ (Mohan and Pittman Jr 2007; Ouvrard et al. 2002).

\section{Adsorption kinetics}

The adsorption kinetics of original and modified VMO were conducted at $\mathrm{pH} 7.0 \pm 0.2$ with the same initial $\mathrm{As}(\mathrm{V})$ concentration of $0.5 \mathrm{mg} / \mathrm{L}$. This kinetics study can help to understand the mechanism of adsorption of $\mathrm{As}(\mathrm{V})$ onto $\mathrm{VMO}$ and its modified forms (Puttamat and Pavarajarn 2016). The

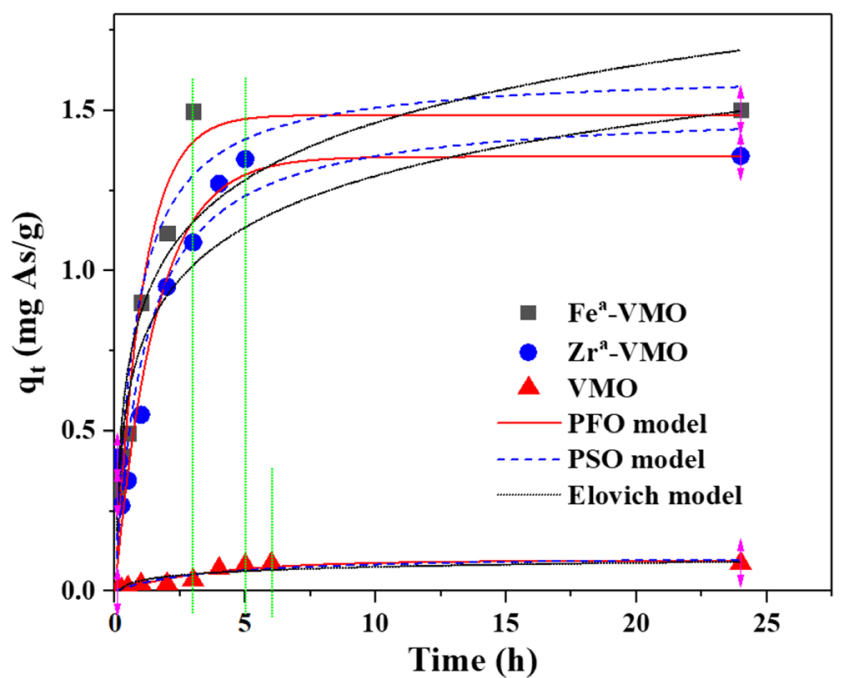

Fig. 8 Adsorption kinetics models fit to the data on $\mathrm{As}(\mathrm{V})$ adsorption on modified and un-modified VMO
Table 5 Parameter values for batch adsorption kinetics

\begin{tabular}{lllll}
\hline \multirow{2}{*}{ Model } & \multirow{2}{*}{ Parameter } & \multicolumn{2}{l}{ Adsorbent } \\
\cline { 3 - 5 } & & $\mathrm{VMO}$ & $\mathrm{Fe}^{\mathrm{a}}-\mathrm{VMO}$ & $\mathrm{Zr}^{\mathrm{a}}-\mathrm{VMO}$ \\
\hline \multirow{4}{*}{ Pseudo-first order } & $q_{\text {exp }}(\mathrm{mg} \mathrm{As} / \mathrm{g})$ & 0.09 & 1.50 & 1.36 \\
& $q_{e}(\mathrm{mg} \mathrm{As} / \mathrm{g})$ & 0.10 & 1.49 & 1.36 \\
& $k_{1}\left(\mathrm{~h}^{-1}\right)$ & 0.26 & 0.96 & 0.63 \\
& $R^{2}$ & 0.92 & 0.94 & 0.88 \\
Pseudo-second order & $q_{e}(\mathrm{mg} \mathrm{As} / \mathrm{g})$ & 0.11 & 1.62 & 1.51 \\
& $k_{2}(\mathrm{~g} / \mathrm{mg} \mathrm{h})$ & 2.42 & 0.82 & 0.59 \\
& $R^{2}$ & 0.89 & 0.94 & 0.88 \\
Elovich & $\alpha(\mathrm{mg} / \mathrm{g} \mathrm{min})$ & 0.002 & 0.125 & 0.105 \\
& $\beta(\mathrm{g} / \mathrm{mg})$ & 53.8 & 3.88 & 4.32 \\
& $R^{2}$ & 0.82 & 0.88 & 0.83 \\
\hline
\end{tabular}

experimental results show that $\mathrm{As}(\mathrm{V})$ was adsorbed rapidly within the first $30 \mathrm{~min}$ when there were enough adsorption sites for As(V) adsorption (Fig. 8). Then, the process slowed down because of the gradual saturation of adsorption sites.

Pseudo-first order (PFO), pseudo-second order (PSO), and Elovich models were applied to investigate the adsorption kinetics of As $(V)$. The values of model parameters and correlation coefficients obtained from the plots are presented in Table 5. According to the values of $R^{2}$, the PFO and PSO models fitted the data comparatively better than the Elovich model.

Finally, the Elovich model was used to describe the kinetics adsorption data. This model also explained the data well, though the $R^{2}$ values were slightly lower than those for PFO and PSO models. The good fit of the model to data is consistent with the chemisorption mechanism (Adeogun and Babu 2015; Firdaous et al. 2017; Önal 2006) for arsenic shown by

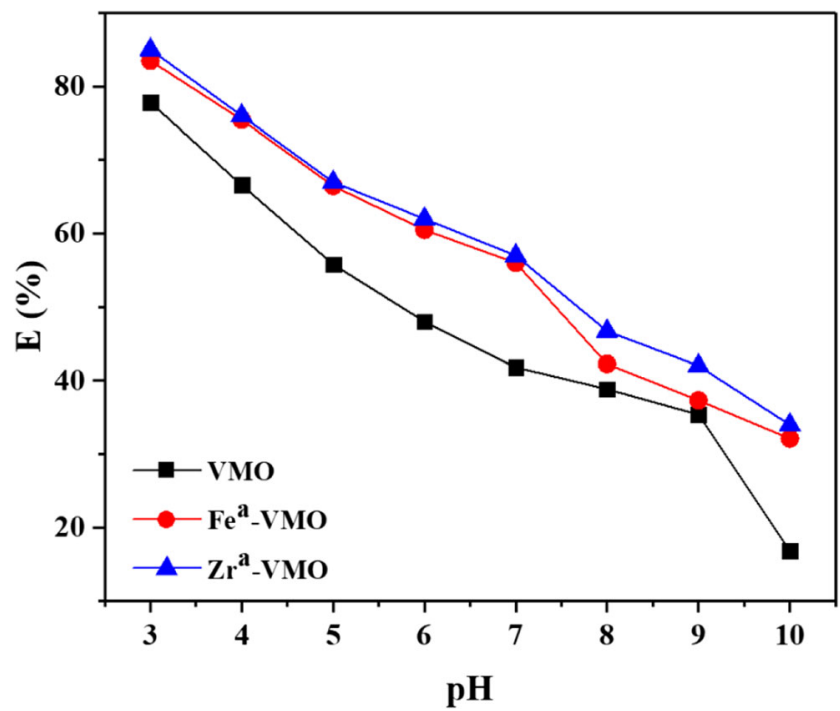

Fig. 9 Influence of $\mathrm{pH}$ on $\mathrm{As}(\mathrm{V})$ removal efficiency of VMO $(3.0 \mathrm{~g} / \mathrm{L})$, $\mathrm{Fe}^{\mathrm{a}}-\mathrm{VMO}(0.3 \mathrm{~g} / \mathrm{L})$, and $\mathrm{Zr}^{\mathrm{a}}-\mathrm{VMO}(0.3 \mathrm{~g} / \mathrm{L})$ 


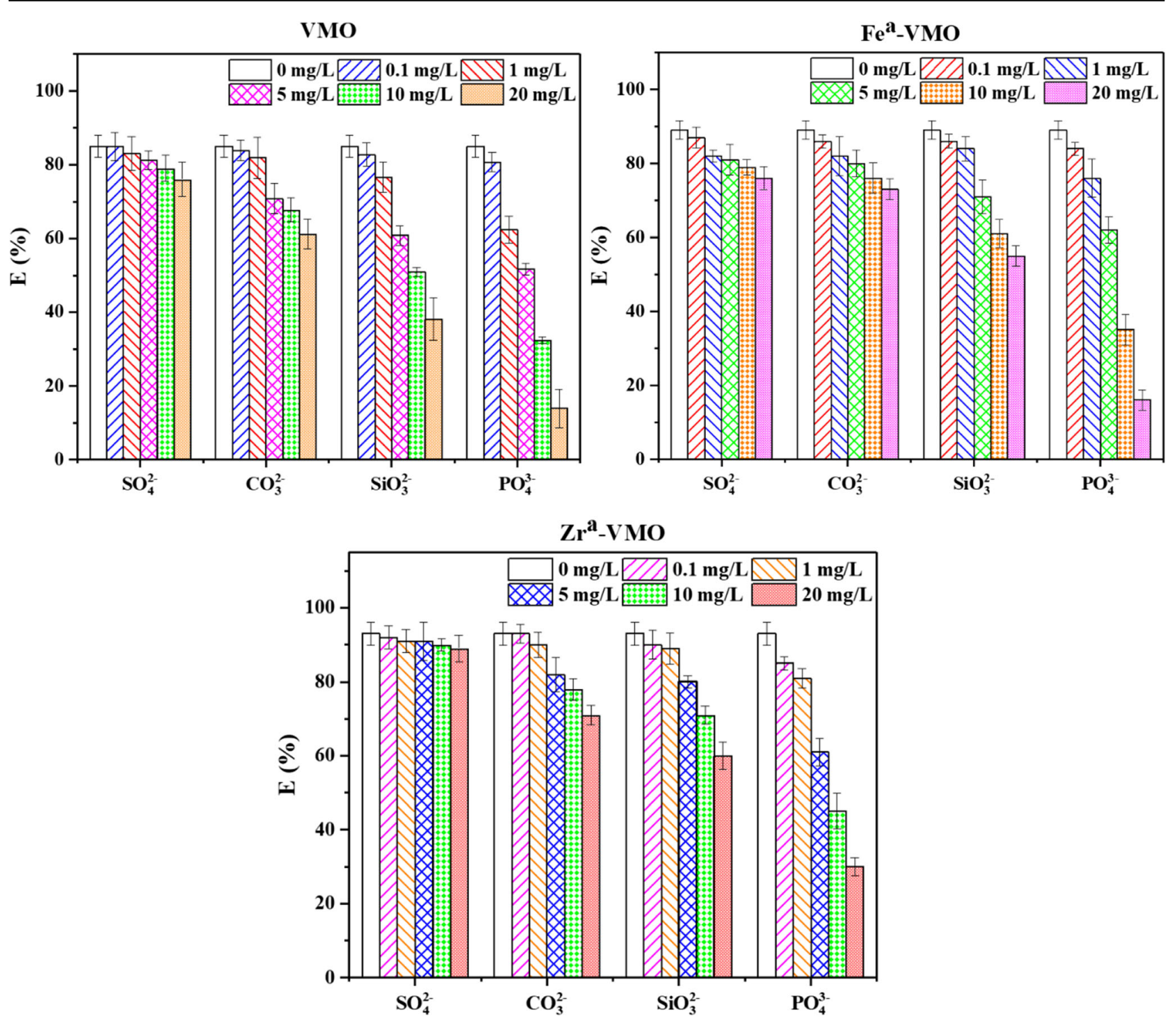

Fig. 10 Effects of co-existing anions on $\mathrm{As}(\mathrm{V})$ removal at fixed initial $\mathrm{As}(\mathrm{V})$ concentration of $0.5 \mathrm{mg} / \mathrm{L}$

zeta potential data. The $\alpha$ value was much higher for $\mathrm{Fe}^{\mathrm{a}}-$ $\mathrm{VMO}$ and $\mathrm{Zr}^{\mathrm{b}}$-VMO than for VMO (Table 5) indicating that the initial rate of adsorption was higher for the modified VMOs. This could be due to the increased affinity of $\mathrm{Fe}$ and $\mathrm{Zr}$ in VMO to arsenic. However, the $\beta$ value which is a reciprocal of the number of sites available for adsorption (Adeogun and Babu 2015) was higher for VMO, indicating that the number of sites available for adsorption was lower for VMO with higher activation energy for chemisorption on VMO (Firdaous et al. 2017).

\section{Influence of pH on $\mathrm{As}(\mathrm{V})$ adsorption}

The $\mathrm{As}(\mathrm{V})$ adsorption depends on the $\mathrm{pH}$ of the solution because $\mathrm{pH}$ affects the protonation/deprotonation of the adsorbate, the surface charge of the adsorbents, the degree of ionization of the surface groups, and the nature of the adsorbing ions (Puttamat and Pavarajarn 2016; Worch 2012). Figure 9 illustrates a significant decline in the $\mathrm{As}(\mathrm{V})$ adsorption efficiency ( $\mathrm{E} \%)$ when the $\mathrm{pH}$ rose from 3 to 10 for all three adsorbents. This phenomenon is due to the decrease in positive zeta potential or increase in negative zeta potential as $\mathrm{pH}$ increased from 3 to 10 (Fig. 4). The increase in surface negative charge repels the negatively charged $\mathrm{As}(\mathrm{V})$ anions. Also, the negative charge on the $\mathrm{As}(\mathrm{V})$ anions increases as $\mathrm{pH}$ increases producing unfavourable conditions for adsorption. Another reason for the decreased adsorption at high $\mathrm{pH}$ is that at high $\mathrm{pH}$, the concentration of $\mathrm{OH}^{-}$anions increases and it competes with $\mathrm{As}(\mathrm{V})$ for adsorption. Others have also reported a reduction in $\mathrm{As}(\mathrm{V})$ adsorption when $\mathrm{pH}$ increases for other adsorbents (Camacho et al. 2011; Wu et al. 2017). 


\section{Effect of co-existing anions on $\mathrm{As}(\mathrm{V})$ adsorption}

In nature, many ions are present along with As in water and some of them can impact the As adsorption ability of an adsorbent. In this study, the prominent anions present in water, $\mathrm{PO}_{4}^{3-}, \mathrm{SO}_{4}^{2-}, \mathrm{SiO}_{3}^{2-}$, and $\mathrm{CO}_{3}^{2-}$, were selected for analysis at different concentrations $(0.1,1,5,10,20 \mathrm{mg} / \mathrm{L})$ to evaluate their effects on $\mathrm{As}(\mathrm{V})$ adsorption.

As can be seen from Fig. 10, at the lowest concentration of $0.1 \mathrm{mg} / \mathrm{L}$, all anions exerted only minor influence on $\mathrm{As}(\mathrm{V})$ adsorption efficiency. When their concentration increased to more than $5 \mathrm{mg} / \mathrm{L}$, the effect of $\mathrm{PO}_{4}^{3-}$ and $\mathrm{SiO}_{3}^{2-}$ was significantly higher than that of $\mathrm{CO}_{3}^{2-}$ and $\mathrm{SO}_{4}^{2-}$. This observation is consistent with previous studies, which reported silicate and phosphate competing with As for adsorption (Ciardelli et al. 2008). The presence of $20 \mathrm{mg} / \mathrm{L}$ of $\mathrm{PO}_{4}^{3-}$ in solution reduced the As removal efficiency of the three adsorbents by about 60 $70 \%$. The effect of $\mathrm{SiO}_{3}^{2-}$ followed that of $\mathrm{PO}_{4}{ }^{3-}$ with reductions of $47 \%, 34 \%$, and $26 \% \mathrm{As}(\mathrm{V})$ removal efficiency of $\mathrm{VMO}, \mathrm{Fe}^{\mathrm{a}}-\mathrm{VMO}$, and $\mathrm{Zr}^{\mathrm{a}}-\mathrm{VMO}$, respectively. This is because these oxyanions were strongly adsorbed by $\mathrm{M}(\mathrm{OH})_{\mathrm{n}}$, where $\mathrm{M}$ is a metal ion such as $\mathrm{Fe}^{3+}, \mathrm{Mn}^{4+}$, and $\mathrm{Zr}^{4+}$. The oxyanion, $\mathrm{CO}_{3}^{2-}$ and $\mathrm{SO}_{4}^{2-}$, did not have much effect on arsenic removal. Consequently, the sequence of competitive anions hindering the sorption of $\mathrm{As}(\mathrm{V})$ is $\mathrm{PO}_{4}^{3-}>\mathrm{SiO}_{3}^{2-}>\mathrm{CO}_{3}^{2-}>\mathrm{SO}_{4}^{2-}$. $\mathrm{Gu}$ et al. (2005) and Ren et al. (2011) also reported that $\mathrm{PO}_{4}{ }^{3-}$ and $\mathrm{SiO}_{3}{ }^{2-}$ reduced $\mathrm{As}(\mathrm{V})$ adsorption on Fe modified GAC more than $\mathrm{CO}_{3}^{2-}$ and $\mathrm{SO}_{4}^{2-}$.

\section{Conclusions}

As a low-cost commercial adsorbent, VMO was employed to remove arsenic from groundwater in many treatment systems in Vietnam. However, the As(V) removal capacity of pure VMO is not sufficiently high.

Mixing VMO with ferric nitrate or zirconium nitrate and sodium hydroxide and heating at $110^{\circ} \mathrm{C}$ and $550{ }^{\circ} \mathrm{C}$ emerged as the best out of four methods of modification of VMO to improve $\mathrm{As}(\mathrm{V})$ removal. The Langmuir adsorption capacities of the modified materials, $\mathrm{Fe}^{\mathrm{a}}-\mathrm{VMO}$ and $\mathrm{Zr}^{\mathrm{a}}-\mathrm{VMO}$, at $\mathrm{pH}$ 7.0 were 2.19 and $1.94 \mathrm{mg} \mathrm{As} / \mathrm{g}$, respectively, which are approximately 20 times higher than that of the unmodified VMO. Zeta potential data showed that the greater $\mathrm{As}(\mathrm{V})$ adsorption by the modified adsorbents could be due to inner-sphere complexation of $\mathrm{As}(\mathrm{V})$ with $\mathrm{Fe}$ and $\mathrm{Zr}$ oxide/hydroxide coatings on $\mathrm{VMO}$, as well as outer-sphere complexation of $\mathrm{As}(\mathrm{V})$ with the $\mathrm{Fe} / \mathrm{Mn}$ coatings which provided increased positive charges for electrostatic adsorption of negatively charged As species. Langmuir, Freundlich, and Temkin models were applied successfully to describe the equilibrium adsorption of $\mathrm{As}(\mathrm{V})$ onto the original and modified VMO. The adsorption kinetics data also fitted well to the three models, pseudo-first order, pseudosecond order, and Elovich models. The $\mathrm{As}(\mathrm{V})$ removal efficiency increased by up to $50-60 \%$ when $\mathrm{pH}$ progressively declined from 10 to 3 . The $\mathrm{PO}_{4}^{3-}$ and $\mathrm{SiO}_{3}^{2-}$ co-ions had a strong competitive effect on $\mathrm{As}(\mathrm{V})$ removal efficiency. In contrast, the ions, $\mathrm{CO}_{3}^{2-}$ and $\mathrm{SO}_{4}^{2-}$, had little influence on $\mathrm{As}(\mathrm{V})$ removal.

Funding information The project was funded by the Australian Government Department of Foreign Affairs and Trade's (DFAT) innovationXchange (iXc).

\section{References}

Adeogun AI, Babu RB (2015) One-step synthesized calcium phosphatebased material for the removal of alizarin $\mathrm{S}$ dye from aqueous solutions: isothermal, kinetics, and thermodynamics studies. Appl Nanosci:1-13

Ahmed MF (2001) An overview of arsenic removal technologies in Bangladesh and India. Proceedings of BUET-UNU international workshop on technologies for arsenic removal from drinking water, Dhaka, Bangladesh, pp 5-7

Altundoğan HS, Altundoğan S, Tümen F, Bildik M (2002) Arsenic adsorption from aqueous solutions by activated red mud. Waste Manag $22: 357-363$

Amini M, Abbaspour KC, Berg M, Winkel L, Hug SJ, Hoehn E, Yang H, Johnson (2008) Statistical modeling of global geogenic arsenic contamination in groundwater. Environ Sci Technol 42:3669-3675

Asere TG, Stevens CV, Du Laing G (2019) Use of (modified) natural adsorbents for arsenic remediation: a review. Sci Total Environ 676: 706-720

Berg M, Stengel C, Trang PTK, Viet PH, Sampson ML, Leng M, Samreth S, Fredericks D (2007) Magnitude of arsenic pollution in the Mekong and Red River Deltas - Cambodia and Vietnam. Sci Total Environ 372:413-425

Berg M, Tran HC, Nguyen TC, Pham HV, Schertenleib R, Giger W (2001) Arsenic contamination of groundwater and drinking water in Vietnam: a human health threat. Environ Sci Technol 35:26212626

Buschmann J, Berg M, Stengel C, Sampson ML (2007) Arsenic and manganese contamination of drinking water resources in Cambodia: coincidence of risk areas with low relief topography. Environ Sci Technol 41:2146-2152

Camacho LM, Parra RR, Deng S (2011) Arsenic removal from groundwater by $\mathrm{MnO}_{2}$-modified natural clinoptilolite zeolite: effects of $\mathrm{pH}$ and initial feed concentration. J Hazard Mater 189:286-293

Chakraborti D, Rahman MM, Paul K, Chowdhury UK, Sengupta MK, Lodh D, Chanda CR, Saha KC, Mukherjee SC (2002) Arsenic calamity in the Indian subcontinent: what lessons have been learned? Talanta 58:3-22

Chakravarty S, Dureja V, Bhattacharyya G, Maity S, Bhattacharjee S (2002) Removal of arsenic from groundwater using low cost ferruginous manganese ore. Water Res 36:625-632

Chiban M, Zerbet M, Carja G, Sinan F (2012) Application of low-cost adsorbents for arsenic removal: a review. Journal of Environmental Chemistry and Ecotoxicology 4:91-102

Ciardelli MC, Xu H, Sahai N (2008) Role of Fe (II), phosphate, silicate, sulfate, and carbonate in arsenic uptake by coprecipitation in synthetic and natural groundwater. Water Res 42:615-624 
Dada A, Olalekan A, Olatunya A, Dada O (2012) Langmuir, Freundlich, Temkin and Dubinin-Radushkevich isotherms studies of equilibrium sorption of $\mathrm{Zn}^{2+}$ unto phosphoric acid modified rice husk. IOSR J Appl Chem 3:38-45

Delva L, Verberckmoes A, Cardon L, Ragaert K (2013) The use of rubber as a compatibilizer for injection moulding of recycled postconsumer mixed polyolefines. 2nd International Conference WASTES: Solutions, Treatments and Opportunities. CVR, Braga, Portugal

Erhayem M, Al-Tohami F, Mohamed R, Ahmida K (2015) Isotherm, kinetic and thermodynamic studies for the sorption of mercury (II) onto activated carbon from Rosmarinus officinalis leaves. American J Ana Chem 6:1

Firdaous L, Fertin B, Khelissa O, Dhainaut M, Nedjar N, Chataigné G, Ouhoud L, Lutin F, Dhulster P (2017) Adsorptive removal of polyphenols from an alfalfa white proteins concentrate: adsorbent screening, adsorption kinetics and equilibrium study. Sep Purif Technol 178:29-39

Gu Z, Fang J, Deng B (2005) Preparation and evaluation of GAC-based iron-containing adsorbents for arsenic removal. Environ Sci Technol 39:3833-3843

Hang C, Li Q, Gao S, Shang JK (2011) As (III) and As (V) adsorption by hydrous zirconium oxide nanoparticles synthesized by a hydrothermal process followed with heat treatment. Ind Eng Chem Res 51: 353-361

Järup L (2003) Hazards of heavy metal contamination. Br Med Bull 68: $167-182$

Jia Y, Xu L, Wang X, Demopoulos GP (2007) Infrared spectroscopic and $\mathrm{X}$-ray diffraction characterization of the nature of adsorbed arsenate on ferrihydrite. Geochim Cosmochim Ac 71:1643-1654

Kabir F, Chowdhury S (2017) Arsenic removal methods for drinking water in the developing countries: technological developments and research needs. Environ Sci Pollut Res 24:24102-24120

Kalaruban M, Loganathan P, Shim W, Kandasamy J, Naidu G, Nguyen $\mathrm{TV}$, Vigneswaran S (2016) Removing nitrate from water using ironmodified Dowex 21K XLT ion exchange resin: batch and fluidisedbed adsorption studies. Sep Purif Technol 158:62-70

Khan TA, Chaudhry SA, Ali I (2013) Thermodynamic and kinetic studies of As (V) removal from water by zirconium oxide-coated marine sand. Environ Sci Pollut Res 20:5425-5440

Loganathan P, Vigneswaran S, Kandasamy J, Bolan NS (2014) Removal and recovery of phosphate from water using sorption. Crit Rev Environ Sci Technol 44:847-907

Maiti A, Basu JK, De S (2010) Development of a treated laterite for arsenic adsorption: effects of treatment parameters. Ind Eng Chem Res 49:4873-4886

Mamindy-Pajany Y, Hurel C, Marmier N, Roméo M (2011) Arsenic (V) adsorption from aqueous solution onto goethite, hematite, magnetite and zero-valent iron: effects of $\mathrm{pH}$, concentration and reversibility. Desalination 281:93-99

Markovski JS, Marković DD, Đokić VR, Mitrić M, Ristić MĐ, Onjia AE, Marinković AD (2014) Arsenate adsorption on waste eggshell modified by goethite, $\alpha-\mathrm{MnO} 2$ and goethite/ $\alpha-\mathrm{MnO}_{2}$. Chem Eng J 237: 430-442

Mohan D, Pittman CU Jr (2007) Arsenic removal from water/wastewater using adsorbents - a critical review. J Hazard Mater 142:1-53

Mondal P, Balomajumder C, Mohanty B (2007) A laboratory study for the treatment of arsenic, iron, and manganese bearing ground water using Fe3+ impregnated activated carbon: effects of shaking time, $\mathrm{pH}$ and temperature. J Hazard Mater 144:420-426

Myneni SC, Traina SJ, Waychunas GA, Logan TJ (1998) Vibrational spectroscopy of functional group chemistry and arsenate coordination in ettringite. Geochim Cosmochim Ac 62:3499-3514

Nur T, Johir M, Loganathan P, Nguyen T, Vigneswaran S, Kandasamy J (2014) Phosphate removal from water using an iron oxide impregnated strong base anion exchange resin. J Ind Eng Chem 20:1301-1307

Oladoja N, Helmreich B (2014) Batch defluoridation appraisal of aluminium oxide infused diatomaceous earth. Chem Eng J 258:51-61

Önal Y (2006) Kinetics of adsorption of dyes from aqueous solution using activated carbon prepared from waste apricot. J Hazard Mater 137:1719-1728

Ouvrard S, Simonnot M-O, Sardin M (2002) Reactive behavior of natural manganese oxides toward the adsorption of phosphate and arsenate. Ind Eng Chem Res 41:2785-2791

Petit T, Puskar L (2018) FTIR spectroscopy of nanodiamonds: methods and interpretation. Diam Relat Mater

Pokhrel D, Viraraghavan T (2008) Arsenic removal from an aqueous solution by modified A. niger biomass: batch kinetic and isotherm studies. J Hazard Mater 150:818-825

Polya D, Gault A, Diebe N, Feldman P, Rosenboom J, Gilligan E, Fredericks D, Milton AH, Sampson M, Rowland HAL (2005) Arsenic hazard in shallow Cambodian groundwaters. Mineral Mag 69:807-823

Puttamat S, Pavarajarn V (2016) Adsorption study for removal of Mn (II) ion in aqueous solution by hydrated ferric (III) oxides. Inter J Chem Eng Appl 7:239-243

Qiu H, Lv L, Pan B-c, Q-j Z, W-m Z, Q-x Z (2009) Critical review in adsorption kinetic models. J Zhejiang University-Sci A 10:716-724

Ren Z, Zhang G, Paul Chen J (2011) Adsorptive removal of arsenic from water by an iron-zirconium binary oxide adsorbent. J Colloid Interface Sci 358:230-237

Shahmohammadi-Kalalagh S (2011) Isotherm and kinetic studies on adsorption of $\mathrm{Pb}, \mathrm{Zn}$ and $\mathrm{Cu}$ by kaolinite. Casp J Environ Sci 9:243255

Smedley PL, Kinniburgh D (2002) A review of the source, behaviour and distribution of arsenic in natural waters. Appl Geochem 17:517-568

Sogaard E (2014) Chemistry of advanced environmental purification processes of water: fundamentals and applications. Elsevier, Amst

Thirunavukkarasu O, Viraraghavan T, Subramanian K (2001) Removal of arsenic in drinking water by iron oxide-coated sand and ferrihydrite-batch studies. Water Qual Res J 36:55-70

Thirunavukkarasu O, Viraraghavan T, Subramanian K (2003) Arsenic removal from drinking water using iron oxide-coated sand. Water Air Soil Pollut 142:95-111

Tomić ZP, Antić-Mladenović SB, Babić BM, Poharc-Logar VA, Đorđević AR, Cupać SB (2011) Modification of smectite structure by sulfuric acid and characteristics of the modified smectite. J Agric Sci 56:25-35

Worch E (2012) Adsorption technology in water treatment: fundamentals, processes, and modeling. Walter de Gruyter

Wu C, Tu J, Liu W, Zhang J, Chu S, Lu G, Lin Z, Dang Z (2017) The double influence mechanism of $\mathrm{pH}$ on arsenic removal by nano zero valent iron: electrostatic interactions and the corrosion of $\mathrm{Fe} 0$. Environ Sci: Nano 4:1544-1552

Wu F-C, Tseng R-L, Juang R-S (2009) Characteristics of Elovich equation used for the analysis of adsorption kinetics in dye-chitosan systems. Chem Eng J 150:366-373

Zhang G, Liu H, Liu R, Qu J (2009) Adsorption behavior and mechanism of arsenate at Fe-Mn binary oxide/water interface. J Hazard Mater 168:820-825

Zhou Z, Y-g L, S-b L, H-y L, G-m Z, Tan X-f, Yang C-p, Ding Y, Z-1 Y, $X-x$ C (2017) Sorption performance and mechanisms of $\operatorname{arsenic}(V)$ removal by magnetic gelatin-modified biochar. Chem Eng J 314: 223-223

Publisher's note Springer Nature remains neutral with regard to jurisdictional claims in published maps and institutional affiliations. 